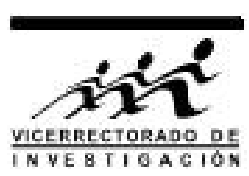

\title{
Investigación de una Muestra Meteorítica Amazónica a través de Técnicas Analíticas
}

\author{
María L. Cerón Loayza ${ }^{*}$, Jorge A. Bravo Cabrejos ${ }^{1}$ y Felipe A. Reyes Navarro ${ }^{2}$ \\ ${ }^{1}$ Laboratorio de Análisis de Suelo, Facultad de Ciencias Físicas, Universidad Nacional Mayor de San Marcos, \\ Calle Germán Amézaga N³75, Lima, Peru. \\ ${ }^{2}$ Laboratorio de Cristales Reales y Aleaciones Metálicas, Facultad de Ciencias Físicas, Universidad Nacional \\ Mayor de San Marcos, Calle Germán Amézaga N³75, Lima, Peru.
}

Recibido 15 julio 2017 - Aceptado 03 octubre 2017

\begin{abstract}
Presentamos el estudio de una muestra meteoritica descubierta en la Amazonía peruana. De acuerdo con el análisis realizado por diferentes técnicas físicas llevadas cabo en un fragmento de este meteorito, éste pertenece a las condritas ordinarias. Específicamente, hemos utilizado la espectroscopía de transmisión Mössbauer y la fluorescencia de rayos $X$ por energía dispersiva. Los resultados con estas técnicas muestran que las muestras tienen cantidades relativamente grandes de Si, Al y Fe. Asimismo, dado que la espectroscopía de transmisión Mössbauer es una técnica isotópicamente más selectiva, hemos observado la presencia de sitios magnéticos asignados a las fases de taenita $(\mathrm{Fe}, \mathrm{Ni})$ y troilita $(\mathrm{Fe}, \mathrm{S})$. También se encontró la presencia de tres dobletes paramagnéticos asignados a $\mathrm{Fe}^{2+}$ : uno asociado con olivino $(\mathrm{Fe}, \mathrm{Mg})_{2} \mathrm{SiO}_{4}$, otro, a piroxeno $(\mathrm{Fe}, \mathrm{Mg}) \mathrm{SiO}_{3}$; y tercer doblete, a un sitio $\mathrm{Fe}^{3+}$.

Palabras claves: condritas, fluorescencia de rayos $\mathrm{X}$ por energía dispersiva, espectroscopia de transmisión Mössbauer.
\end{abstract}

\section{A Study about a Amazonian Meteoritic Specimen by Analytical Techniques}

Herein, it is introduced the analysis of a meteoritic specimen discovered in the Peruvian Amazonia. According to the analysis by different physical techniques carried onto a fragment of it, this meteorite belongs to the ordinary chondrites. Specifically, we have used transmission Mössbauer spectroscopy and energy dispersive $\mathrm{X}$-ray fluorescence. The results with these techniques show that the samples have relatively large amounts of $\mathrm{Si}, \mathrm{Al}$ and Fe. Likewise, since transmission Mössbauer spectroscopy is an isotopically more selective technique, we have observed the presence of magnetic sites assigned to the taenite $(\mathrm{Fe}, \mathrm{Ni})$ and troilite $(\mathrm{Fe}, \mathrm{S})$ phases. We also realized the presence of three paramagnetic doublets assigned to $\mathrm{Fe}^{2+}$ : one associated with olivine $(\mathrm{Fe}, \mathrm{Mg})_{2} \mathrm{SiO}_{4}$; other, to pyroxene $(\mathrm{Fe}, \mathrm{Mg}) \mathrm{SiO}_{3}$; and third doublet, to one $\mathrm{Fe}^{3+}$ site.

Palabras claves: chondrites, energy dispersive X-ray fluorescence, transmission Mössbauer spectroscopy.

\section{Introduction}

In continuing our investigations about the fall of meteorites occurred in Peru [1-3], we have incidentally obtained an alleged meteorological sample, which was found in the Madre de Dios Region, in the Peruvian Amazonia. Thus, we must also point out that trading and smuggling of meteorites have already been initiated in the Republic of Peru.

We have subjected the corresponding meteoritic sample to energy dispersive $\mathrm{X}$-ray fluorescence (EDXRF) and to transmission Mössbauer spectroscopy (TMS). The for- mer was used to determine its elemental composition and the latter, to determine its chemical and phase composition. TMS is a technique useful to study meteorites and especially chondrites, because it is an isotopically selective technique.

Ordinary chondrites normally contain metal phases (FeNiCo alloys), troilite $(\mathrm{FeS})$, olivine $\left[\left(\mathrm{Mg}, \mathrm{Fe}^{2+}\right)_{2} \mathrm{SiO}_{4}\right]$, augite $(\mathrm{NaCa})(\mathrm{Mg}, \mathrm{Fe}, \mathrm{Al})(\mathrm{Al}, \mathrm{Si})_{2} \mathrm{O}_{6}$ and sometimes iron oxides like ferric oxide or hydrated oxides - from now on, augite will be called pyroxene because it is the most frequent pyroxene. Besides, ordinary chondrites can be classified into three groups: H, L and LL. These groups are cha-

*malucelo.hotmail.com 
racterized by a different total content of iron and nickel. The contents by weight of metallic iron in these chondrite groups are, respectively, $15-19 \%(\mathrm{H}), 4-10 \%(\mathrm{~L})$ and $1-3 \%$ (LL) [4]. In our results, we detected the presence of troilite and taenite in ordinary chondrite; we determined its percentage as well as differentiate its main metallic phases..

\section{Materials and Methods}

The owner of the meteorite provided us with a small fragment, which was yellowish-gray. Shortly after the receipt,we convey the small fragment toward the Soil Analysis Laboratory of the UNMSM (SAL) to verify its authenticity by carrying out the corresponding tests and analyses. In the SAL, the fragment provided to us was ground in an agate mortar; afterwards, we obtained a fine $160 \mu \mathrm{m}$ mesh powder of approximately $180 \mathrm{mg}$.

In Fig. 1, we observe a photograph of the meteoritic specimen; the picture was sent to us by the possessor of the meteorite in 2016. The total specimen weighs about 5 $\mathrm{kg}$ and has both a granular aspect and a size about $20 \mathrm{~cm}$. On the surface, it shows gaps and spherical parts; striation is notorius. Probably, in crossing the earth's atmosphere, due to high pressures and temperatures, it was deformed by burning [7-[11].

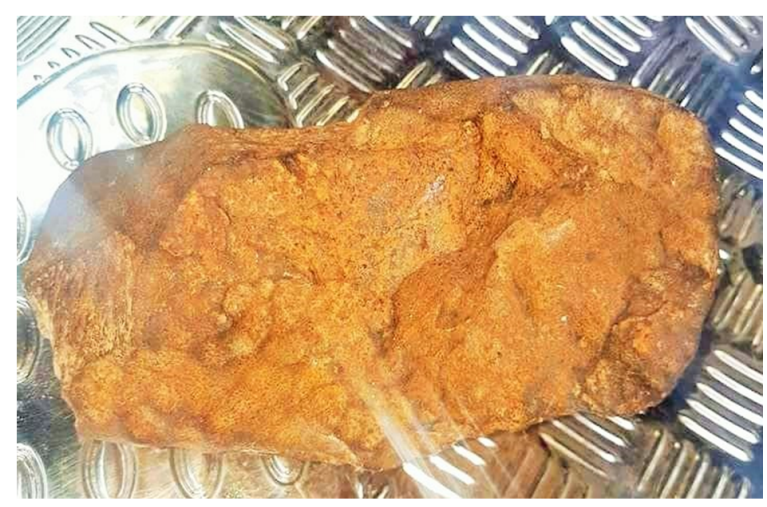

Figure 1: Photograph of the meteoritic specimen. On the bottom left,we observe circular formations, which are possibly provoked bythe high pressures and temperatures when it impacted into the Earth.

\subsection{Energy dispersive $X$-ray fluorescence (EDXRF)}

In order to obtain the elemental composition, we used a portable EDFRX AMPTEK instrument, which uses an $X$-ray tube with a silver cathode operating at $30 \mathrm{kV}$ and about $30 \mu \mathrm{A}$.

Figure 2 shows the corresponding experimental spectrum, wherein we have identified the characteristic $X$-ray peaks of the elements present in the sample. We have also detected the characteristic $x$-rays of argon from the air and the dispersed $X$-rays of gold from the source we used. In addition to the experimental spectrum, Figure 2 shows a blue color curve that corresponds to the theoretical simulation of the spectrum, on which the quantitative interpretation of the spectrum is based.

Likewise, Table 1 shows the quantitative elemental composition of the sample expressed in terms of the relative mass percent composition of elements having an atomic number equal and greater than 13 . If the sample had lighter elements such as magnesium, sodium, boron or beryllium, they would be unnoticed unless additional information is available. The uncertainty estimated in these measurements of the elemental concentration is about $10 \%$.

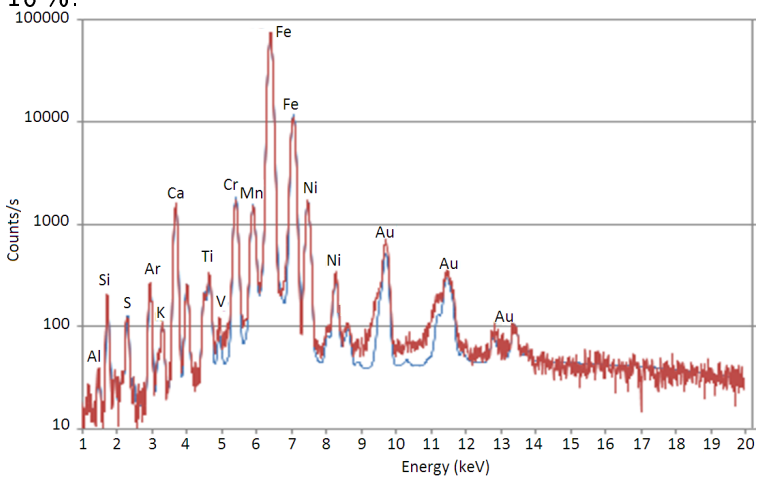

Figure 2: In a semilogarithmicplot, the EDFRX experimental spectrum of themeteoritic sample from the Peruvian Amazonia.

Table 0: Mass percent composition of the meteoritic sample from the Peruvian Amazonia.

\begin{tabular}{cccc}
\hline Compound & $\%$ & Element & $\%$ \\
\hline $\mathrm{Al}_{2} \mathrm{O}_{3}$ & 16.50 & $\mathrm{Al}$ & 8.733 \\
$\mathrm{SiO}_{2}$ & 41.82 & $\mathrm{Si}$ & 19.548 \\
$\mathrm{Fe}_{2} \mathrm{O}_{3}$ & 24.18 & $\mathrm{Fe}$ & 16.912 \\
$\mathrm{CaO}$ & 2.65 & $\mathrm{Ca}$ & 1.894 \\
$\mathrm{CuO}$ & 0.01 & $\mathrm{Cu}$ & 0.008 \\
$\mathrm{~K}_{2} \mathrm{O}$ & 2.94 & $\mathrm{~K}$ & 2.441 \\
$\mathrm{SO}_{2}$ & 4.76 & $\mathrm{~S}$ & 2.382 \\
$\mathrm{TiO}_{2}$ & 0.20 & $\mathrm{Ti}$ & 0.120 \\
$\mathrm{Cr}_{2} \mathrm{O}_{3}$ & 0.89 & $\mathrm{Cr}$ & 0.609 \\
$\mathrm{MnO} \mathrm{O}$ & 0.45 & $\mathrm{Mn}$ & 0.349 \\
$\mathrm{Ni}_{2} \mathrm{O}_{3}$ & 0.61 & $\mathrm{Ni}$ & 0.433 \\
$\mathrm{~V}_{2} \mathrm{O}_{3}$ & 0.01 & $\mathrm{~V}$ & 0.007 \\
\hline Subtotal & 95.02 & Subtotal & 53.436 \\
Others & 4.98 & Others & 46.564 \\
\hline Total & 100.00 & Total & 100.00 \\
\hline \multicolumn{4}{c}{}
\end{tabular}




\section{2. ${ }^{57}$ Fe transmission Mössbauer spectroscopy (TMS)}

This technique is useful to obtain detailed information about mineral phases that contain iron. Thus, we placed $180 \mathrm{mg}$ of the sample inside of a sample holder of $1.7 \mathrm{~cm}$ internal diameter. Afterwards,we subjected it to gamma radiation of $14.413 \mathrm{keV}$ from a radioactive ${ }^{57}$ Co source in an Rh matrix. As usual, aconventional spectrometer was utilized; it has a sinusoidal velocity modulation signal and 1024 channels. The Mössbauer spectrum at room temperature of the sample was collected at the LAS. This spectrum was analyzed by using the Normos program invented by R. A. Brand in its crystalline sites version (Normos Site) [5].

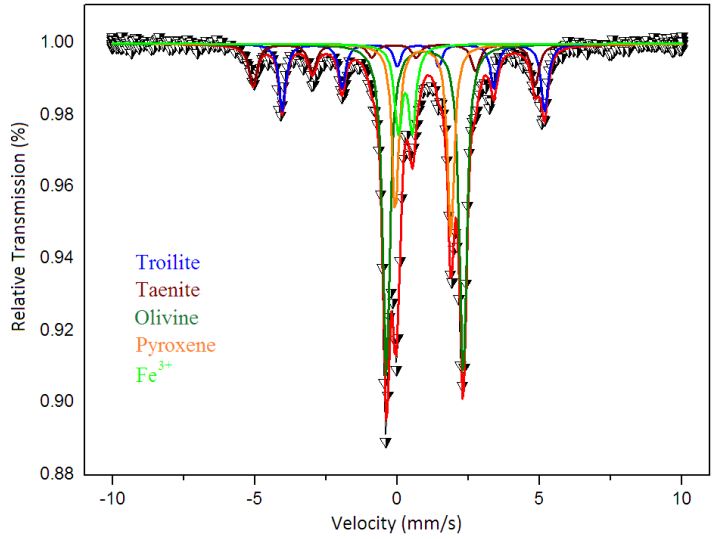

Figure 3: Mössbauer spectrum of the meteoritic sample From the Peruvian Amazonia taken at room temperature.

Table 2: Hyperfine parameters of the meteoritic sample.

\begin{tabular}{ccccc}
\hline \multicolumn{5}{c}{ Carancas } \\
\hline Mineral Phases & $\begin{array}{c}\text { ISO } \\
(\mathrm{mm} / \mathrm{s})\end{array}$ & $\begin{array}{c}\text { QUA } \\
(\mathrm{mm} / \mathrm{s})\end{array}$ & $\begin{array}{c}\mathrm{B}_{\mathrm{hf}} \\
(\mathrm{T})\end{array}$ & $\begin{array}{c}\mathrm{A} \\
(\%)\end{array}$ \\
\hline Kamacite/Taenite & -0.110 & 0.00 & 33.67 & 11.712 \\
Troilite & 0.648 & -0.16 & 31.38 & 15.918 \\
Olivine & 1.036 & 2.95 & 40.580 & \\
Pyroxene & 1.035 & 2.18 & & 21.012 \\
$\mathrm{Fe}^{3+}$ & 0.223 & 0.458 & & 10.777 \\
\hline
\end{tabular}

\section{Discussion and Results}

The analysis by EDFRX of the sample showed the presence of the following oxides: $\mathrm{Al}_{2} \mathrm{O}_{3}, \mathrm{SiO}_{2}, \mathrm{SO}_{2}, \mathrm{CuO}$, $\mathrm{K} 2 \mathrm{O}, \mathrm{CaO}, \mathrm{TiO}_{2}, \mathrm{Cr}_{2} \mathrm{O}_{3}, \mathrm{MnO}, \mathrm{Fe}_{2} \mathrm{O}_{3}, \mathrm{Ni}_{2} \mathrm{O}_{3}$ and $\mathrm{V}_{2} \mathrm{O}$ (see Table 1). We notice as follows: high concentrations of $\mathrm{Si}>$ Fehigh concentrations of $\mathrm{Al}$, intermediate concentrations such as $\mathrm{S}>\mathrm{K}>\mathrm{Ca}$, minor concentrations of $\mathrm{Cr}>\mathrm{Ni}>\mathrm{Mn}>\mathrm{Ti}$. Cupper and vanadium are practically scarce. As shown in Figure 3, the spectrum taken at RT was fitted by two magnetic sextets and by three doublets paramagnetic. The two sextets were respectively as- signed to troilite (FeS) and the FeNi phase known as kamacite; meanwhile, two of the doublets were assigned to paramagnetic $\mathrm{Fe}^{2+}$ doublets (the one associated to olivine $(\mathrm{Fe}, \mathrm{Mg})_{2} \mathrm{SiO}_{4}$ and the other to pyroxene $(\mathrm{NaCa})(\mathrm{Mg}, \mathrm{Fe}, \mathrm{Al})(\mathrm{Al}, \mathrm{Si})_{2} \mathrm{O}_{6}$ The third doublet was assigned to one $\mathrm{Fe}^{3+}$ site. Consequently, Table 2 shows the respective hyperfine parameters of the different mineral phases found in the meteoritic sample taken at room temperature. The iron minerals with higher concentrations, identified in the TMS spectrum, agree with those from the EDFRX spectrum. This because $0.6 \% \mathrm{Ni}$ observed would correspond to the metal phase of the kamacite observed by TMS. Besides, $24.18 \%$ Fe would be distributed in all phases given by the areas; the high percentage of $\mathrm{Si}$ is distributed between the paramagnetic phases of olivine and pyroxene. By using aforementioned techniques, the results show a correlation.

\section{Conclusions}

Through the analysis by EDFRX, we have identified the presence of the following compounds: $\mathrm{Al}_{2} \mathrm{O}_{3}, \mathrm{SiO}_{2}$ and $\mathrm{Fe}_{2} \mathrm{O}_{3}$ in relatively high concentrations. Likewise, the analysis by TMS at room temperature allowed us the observation of magnetic and paramagnetic phases, some of which are super imposed on others. The FeNi phases can be related to kamacite, that is, we have found metallic phases corresponding to a meteoritic sample. Therefore, the investigated sample can be classified as a meteorite belonging to the ordinary chondrites.

\section{Acknowledgments}

Special thanks to the staff of the Laboratory of Soil Analysis and the Laboratory of Archaeometry of the National University of San Marcos, their collaboration was invaluable.

\section{Referencias}

[1] M. L. Cerón Loayza and J. A. Bravo Cabrejos. Caracterización mineralógica de un impacto meteoritico en la localidad de Carancas-Puno (Mineralogical characterization of a meteorological impact in Carancas, Puno). Revista de Investigación de Física12, № 1 , 5-12, UNMSM (2009).

[2] M.L. Cerón Loayza and J.A. Bravo Cabrejos. Characterization of the Carancas-Puno meteorite by energy dispersive X-ray fluorescence, X-ray diffractometry and transmission Mössbauer spectroscopy. Hyperfine Interact. Vol. 203, Iss. 1-3,17-23(2011).

[3] M.L. Cerón Loayza and J.A. Bravo Cabrejos. Minerals of a soil developed in the meteoritic crater of 
Carancas, Peru, and evidences of phase changes on the impact event. Hyperfine Interact. 224, Iss. 1-3, 143-152 (2014).

[4] E.V. Zhiganova, M.I. Oshtrakh, O.B. Milder et al. Mössbauer spectroscopy of ordinary chondrites: an analysis of the metal phases. Hyperfine Interact.166, Iss, 1-4, 665-670 (2005).

[5] R.A. Brand. Normos Mössbauer Fitting Program, User's Guide. Wissenschaftlich Elektronik $\mathrm{GmbH}$, Starnberg (1995).

[6] Langenhorst, F. and Deutsch. "Minerals in terrestrial impact structures and their characteristic features," In: Advanced mineralogy 3, pp. 95-119, Ed.A. S. Marfunin, Springer-Verlag, Berlin (1998).

[7] Kieffer, S.W., Phakey, P.P. and Christie J.M. Shock processes in porous quartzite: transmission electron microscope observations and theory. Contrib. Mineral. Petrol. 59, No. 1, 41-93 (1976).

[8] Hemley, R.J., Prewitt, C.T. and Kingma, K.J. High pressure behavior of silica. Rev. Mineral 29, 41-82 (1994).

[9] Chao, E.C.T., Fahey, J.J., Littler, J. and Milton, D.J. Stishovite, SiO2, a very high pressure new mineral from meteor crater, Arizona. J. Geophys. Res. 67(1), 419-421 (1962).

[10] Wackerle, J. Shock-wave compression of quartz. J. Appl. Phys. 33, Iss. 3, 922-937 (1962).

[11] Yang, C. W., Williams, D. B. and Goldstein J. I. Lowtemperature phase decomposition in metal from iron, stony-iron, and stony meteorites. Geochim. Cosmochim. Acta 61, 2943-2956 (1997). 